\title{
KONDISI EKOLOGI MANGROVE DI PULAU MANTEHAGE KECAMATAN WORI KABUPATEN MINAHASA UTARA PROVINSI SULAWESI UTARA
}

\author{
(Mangrove Ecological Conditions in Mantehage Island, Wori District \\ North Minahasa Regency, North Sulawesi Province)
}

\author{
Yostan Lahabu $^{1^{*}}$, Joshian N.W. Schaduw ${ }^{1}$, Agung B. Windarto ${ }^{1}$
}

1. Program Studi IImu Kelautan, Fakultas Perikanan dan IImu Kelautan, Universitas Sam Ratulangi, Manado

“e-mail :yostanlahabu91@gmail.com

Mangrove is a plant that grows between the tidal lines. Mangrove forest plays important ecological and economical functions, but highly vulnerable to damage if less wise in maintaining, preserving and management. This study had been conducted in Mantehage Island District of Wori, North Minahasa Regency, North Sulawesi Province.The aims of this study were to identify mangroves types and to determine the ecological conditions of mangrove forest vegetation in Mantehage Island. The method used was the line transects method. The data was processed with community structure analysis. There were 8 mangrove species being identified in Mantehage Is., those are : Rhizophora mucronata, Rhizophora apiculata, Rhizophora stylosa, Bruguiera gymnorrhiza, Bruguiera cylindrical, Ceriops tagal, Sonneratia alba, and Lumnitzera littorea. Result of the analysis showed mangrove ecosystem was in stable condition yet. It is based on the value of the diversity index in the low category $\left(H^{\prime}=0,93, H^{\prime}=0,91, H^{\prime}=1,07\right.$, $\left.H^{\prime}=1,38\right)$. The uniformi index value of seedlings, saplings, poles and trees from four stations showed an evenly value (seedling $=0.95$, saplings $=0.82$, poles $=64$ and trees $=0,85$ ). While the dominance index value indicates a high value (seedling $=0,66$, saplings $=1.00$, poles $=$ 0.61 and trees $=0,37$ ). Environmental factors such as temperature and salinity ranged from 29 to33 ppt while temperature ranged from 27 tp $30^{\circ} \mathrm{C}$. These values are excellent for mangroves growth.

Keywords: Mangrove, Ecology, Condition, Mantehage Island

Mangrove adalah tumbuhan yang tumbuh diantara garis pasang surut. Hutan mangrove memiliki fungsi ekologis dan ekonomis yang sangat penting, tetapi sangat rentan terhadap kerusakan apabila kurang bijaksana dalam mempertahankan, melestarikan dan pengelolaannnya. Penelitian ini dilakukan di Pulau Mantehage Kecamatan Wori Kabupaten Minahasa Utara Provinsi Sulawesi Utara. Tujuan penelitian ini adalah untuk mengidentifikasi jenis-jenis mangrove dan mengetahui kondisi ekologi vegetasi hutan mangrove yang terdapat di kawasan Pulau Mantehage. Metode yang digunakan yaitu metode line transek kuadran. Data yang didapatkan selanjutnya diolah dengan analisis struktur komunitas. Terdapat 8 jenis mangrove yang teridentifikasi di Pulau Mantehage, yaitu : Rhizophora mucronata, Rhizophora apiculata, Rhizophora stylosa, Bruguiera gymnorrhiza, Bruguiera cylindrical, Ceriops tagal, Sonneratia alba, dan Lumnitzera littorea. Hasil analisis vegetasi mangrove menunjukkan ekosistem dalam keadaan belum stabil $\mathrm{Hal}$ ini didasarkan pada nilai indeks keanekaragaman yang masuk dalam kategori rendah $\left(H^{\prime}=0,93, H^{\prime}=0,91, H^{\prime}=1,07, H^{\prime}=1,38\right)$. Nilai indeks keseragaman dari tingkat semai, pancang, tiang dan pohon dari empat stasiun menunjukkan nilai yang merata (tingkat Semai $=0,95$, Pancang=0,82, Tiang=64 dan Pohon=0,85). Sedangkan nilai indeks dominansi menunjukkan nilai yang tinggi (tingkat Semai $=0,66$, Pancang $=1,00$, Tiang $=0,61$ dan Pohon=0,37). Faktor lingkungan seperti suhu dan salinitas menunjukkan nilai kisaran 29-33 ppt untuk salinitas dan 27-30 ${ }^{\circ} \mathrm{C}$ untuk suhu. Nilai ini tergolong baik untuk pertumbuhan mangrove.

Kata kunci: Kondisi, Ekologi, Mangrove, Pulau Mantehage. 


\section{PENDAHULUAN}

Hutan Mangrove merupakan salah satu bentuk ekosistem hutan yang unik dan khas, terdapat di daerah pasang surut di wilayah pesisir, pantai, dan atau pulau-pulau kecil dan merupakan sumberdaya alam yang sangat potensial. (Waryono, 2002). Menurut Nybakken (1992), hutan mangrove adalah sebutan umum yang digunakan untuk menggambarkan suatu varietas komunitas pantai tropik yang didominasi oleh beberapa spesies pohon-pohon yang khas atau semak-semak yang mempunyai kemampuan untuk tumbuh dalam perairan asin. Hutan mangrove meliputi pohon-pohon dan semak yang tergolong ke dalam 8 famili, dan terdiri atas 12 genera tumbuhan berbunga : Avicennie, Sonneratia, Rhyzophora, Bruguiera, Ceriops, Xylocarpus, Lummitzera, Laguncularia, Aegiceras, Aegiatilis, Snaeda, dan Conocarpus (Bengen, 2004).

Tujuan dari penelitian ini yaitu : Mengidentifikasi jenis mangrove yang ada di Pulau Mantehage, mengetahui kondisi ekologi vegetasi hutan mangrove melalui kajian analisis data yaitu Kerapatan, Frekuensi, Penutupan, Indeks Nilai Penting, Keanekaragaman, Kekayaan, Keseragaman, Dominansi dan faktor pembatas (Salinitas, Suhu dan Subsrat) yang terdapat di kawasan Pulau Mantehage.

\section{METODE PENELITIAN}

\section{Tempat dan Waktu}

Penelitian ini telah dilaksanakan pada bulan Juli sampai bulan November 2015 yang berlokasi di Pulau Mantehage Kecamatan Wori Kabupaten Minahasa Utara, Provinsi Sulawesi Utara. Stasiun pengamatan ditentukan pada 2 (dua) lokasi yaitu Desa Tangkasi, dan Desa Bango. Namun, khusus untuk pengamatan lapangan dilaksanakan pada tanggal 16 - 21 Juli 2015.

\section{Metode Pengambilan Data}

Metode penelitian ini menggunakan metode Line Transek Kuadrat. Cara ini dilakukan dengan menghitung Nilai Kerapatan, Frekuensi, Penutupan, Nilai Penting, Keanekaragaman, Kekayaan, Kemerataan, dan Indeks dominansi.

Untuk pengamatan dilakukan transek dengan metode kuadrat setiap stasiun pengamatan, tetapkan transek-transek garis dari arah laut ke arah darat (tegak lurus garis). Pada setiap zona hutan mangrove yang berada di sepanjang transek garis, letakan secara acak petakpetak contoh (plot) berbentuk bujur sangkar dengan ukuran $20 \mathrm{~m}$ x $20 \mathrm{~m}$ sebanyak paling kurang 3 (tiga) petak contoh (plot). Ukuran kuadrat berukuran $20 \times 20$ m untuk tanaman berdiameter > $20 \mathrm{~cm}$ yang disebut pohon, untuk kuadrat berukuran $10 \times 10 \mathrm{~m}$ diletakkan di dalam kuadrat $20 \times 20 \mathrm{~m}$ untuk tanaman berdiameter $10 \leq 20 \mathrm{~cm}$ yang disebut tiang, sedangkan ukuran $5 \times 5 \mathrm{~m}$ dan diletakkan di dalam kuadrat $10 \times 10 \mathrm{~m}$ dapat digunakan untuk tanaman berdiameter $<10 \mathrm{~cm}$ (ketinggian $>1,5 \mathrm{~m}$ ) yang disebut pancang, dan $2 \times 2 \mathrm{~m}$ di dalam petak $5 \times 5 \mathrm{~m}$ yang disebut semai (belta). Pengambilan data dalam penelitian ini antara lain : Jenis mangrove, jumlah tegakan, diameter batang setinggi dada (DBH), mengukur kualitas air (salinitas dan suhu) dengan menggunakan alat Water parameter eutech instrument COND 610. Sedangkan Subsrat diamati secara visual dari fisik tekstur, lalu dicatat tipe subsratnya di setiap kuadran dalam satu stasiun pengamatan. Tipe subsrat diperoleh dengan cara merabah, merasakan struktur fisik tekstur secara kasar yaitu pasir, liat atau lumpur.

\section{Metode Analisis Data Kondisi Vegetasi}

Data-data mengenai jenis, jumlah tegakan dan diameter pohon yang telah dicatat, diolah lebih lanjut untuk 
memperoleh Kerapatan Jenis, Frekuensi Jenis, Luas Area Penutupan, Indeks Nilai Penting, Keanekaragaman, Kekayaan, Kemerataan dan Dominansi sebagaimana dapat dilihat dibawah ini :

1. Kerapatan jenis (Di) (Bengen, 2004). $\mathrm{Di}=\frac{\text { Jumlahtotal individu spesies }}{\text { Luas petakpengamatan }}$

2. Kerapatan relatif (RDi) (Bengen, 2004).

$\mathrm{RDi}=\frac{\text { Kerapatan suatu jenis }}{\text { Kerapatan seluruhjenis }} \times 100 \%$

3. Frekuensi jenis (Fi) (Bengen, 2004). $\mathrm{F} 1=\frac{\mathrm{Jmlh} \text { petak ditemukannya suatu jenis }}{\mathrm{Jmlh} \text { seluruhpetak/plot pengamatan }}$

4. Frekuensi relatif (RFi) (Bengen, 2004).

$\mathrm{RFi}=\frac{\text { Frekuensi suatu jenis }}{\text { Frekuensiseluruhjenis }} \times 100 \%$

5. Penutupan jenis (Ci) (Bengen, 2004). $\mathrm{Ci}=\frac{\mathrm{Jmlh} \text { Basalarea DBH jenisi }}{\text { Luas total area pengambilan contoh (plot) }}$

6. Penutupan relatif (RCi) (Bengen, 2004).

$\mathrm{RC}=\frac{\text { Luas penutupan jenis ke }-\mathrm{i}}{\text { Total luas area penutupan seluruh jenis }} \times 10$ $0 \%$

7. Dari hasil perhitungan rumus diatas kemudian dihitung indeks nilai penting (INP) dengan menggunakan rumus Bengen (2004).

$\mathrm{INP}=\mathrm{RDi}+\mathrm{RFi}+\mathrm{RCi}$

Untuk tingkat semai dan pancang, formula INP adalah sebagai berikut:

$\mathrm{INP}=\mathrm{RDi}+\mathrm{RFi}$

8. Keanekaragaman

Indeks keanekaragaman (Odum, 1971).

$\mathrm{H}^{\prime}=-\sum_{\mathrm{i}=1}^{\mathrm{n}}\left(\frac{\mathrm{ni}}{\mathrm{N}} \ln \frac{\mathrm{ni}}{\mathrm{N}}\right)$

Keterangan :

$$
\begin{gathered}
\mathrm{H}^{\prime}: \text { Indeks Keanekaragaman } \\
\mathrm{Pi}: \text { Proposi jumlah individu } \\
\text { spesies ke-i }(\mathrm{ni} / \mathrm{n}) \\
\mathrm{Ni}: \begin{array}{c}
\text { Jumlah individu suatu } \\
\text { jenis }
\end{array} \\
\mathrm{N}: \text { Jumlah total individu }
\end{gathered}
$$

Kriteria Keanekaragaman (Odum, 1971) :

$\mathrm{H}^{\prime}<1$ : Keanekaragaman rendah dan keadaan komunitas rendah

$1<\mathrm{H}^{\prime}<3 \quad$ : Keanekaragaman sedang dan keadaan komunitas sedang

$\mathrm{H}^{\prime}>3$ : Keanekaragaman tinggi dan keadaan komunitas tinggi.

9. Indeks Kekayaan, Spesies Margalef (SR) (Ludwig and Reynold, 1988).

$S R=(s-1) / \ln (M)$

Keterangan:

$s$ : jumlah total spesies

$N$ : jumlah total individu.

10. Indeks Keseragaman (Odum, 1971).

$\mathrm{E}=\frac{\mathrm{H}^{*}}{\mathrm{H}}$

Keterangan :

$\mathrm{E} \quad$ : Indeks keseragaman

$\mathrm{H}^{\prime} \quad$ : Indeks Keragaman

$\mathrm{H}_{\max }$ : Ln S

$S$ : Jumlah spesies

Dari perbandingan ini didapat suatu nilai yang besarnya antara 0 dan 1 .

11. Indeks Dominansi (Odum,1971).

$$
\mathrm{C}=\sum_{\mathrm{t}-1}^{\mathrm{s}}(\mathrm{Pi})^{2}
$$

Keterangan :

C : indeks dominansi Simpson

$\mathrm{S} \quad$ : jumlah jenis

$\mathrm{Pi} \quad: \mathrm{ni} / \mathrm{N}$

ni : Jumlah Individu jenis ke-i

$\mathrm{N}$ : Jumlah total individu

Dengan kriteria (Odum, 1971) :

Jika nilai $0<D \leq 0,5$ maka Dominansi rendah

Jika nilai $0,5<\mathrm{D} \leq 0,75$, maka Dominansi sedang

Jika nilai $0,75<D \leq 1,00$, maka Dominansi tinggi

Nilai $D$ berkisar antara $0-1$ artinya :

Jika nilai $C$ mendekati 0 , berarti hampir tidak ada individu yang hidup 


\section{HASIL DAN PEMBAHASAN}

\section{Jenis-Jenis Mangrove dan Analisis Vegetasi Mangrove}

Pengamatan dilakukan pada dua stasiun dengan jarak yang berbeda-beda. Berdasarkan hasil identifikasi dan pengamatan diperoleh 8 jenis mangrove yang terdiri dari tiga famili. Jenis-jenis yang ada yaitu : Rhizophora apiculata, Rhizophora stylosa, Rhizophora mucronata, Bruguiera gymnorrhiza, Bruguiera cylindrical, Sonneratia alba, Ceriops tagal, Lumnitzera littorea, jenisjenis mangrove tersebut termasuk dalam famili Rhizophoraceae, Sonneratiaceae, dan Combretaceae. Jenis mangrove yang di stasiun 1 ditemukan 7 jenis mangrove yaitu Rhizophora apiculata, Rhizophora mucronata, Bruguiera gymnorrhiza, Bruguiera cylindrical, Sonneratia alba, Lumnitzera littorea, Ceriops tagal. Stasiun 2 ditemukan 4 jenis mangrove yaitu Rhizophora apiculata, Rhizophora stylosa, Bruguiera gymnorrhiza dan Sonneratia alba.

\section{Kerapatan Jenis dan Kerapatan Relatif}

Nilai kerapatan jenis tertinggi pada tingkat Semai di stasiun 1 nilai tertinggi dimiliki oleh $R$. mucronata yaitu 0,75 ind $/ \mathrm{m}^{2}$, diikuti oleh $R$. apiculata yaitu $0,33 \mathrm{ind} / \mathrm{m}^{2}$, dan yang terendah adalah B. gymnorrhiza yaitu $0,17 \mathrm{ind} /$ $\mathrm{m}^{2}$, sedangkan masing-masing jenis tersebut memiliki nilai kerapatan relatif sebesar $60 \%, 26,67 \%$ dan $13,33 \%$. Nilai Stasiun 2 nilai tertinggi dimiliki oleh $R$. stylosa yaitu $0,42 \mathrm{ind} / \mathrm{m}^{2}$, dan yang terendah adalah $R$. apiculata yaitu 0,25 ind $/ \mathrm{m}^{2}$, sedangkan masing-masing jenis tersebut memiliki nilai kerapatan relatif sebesar $62,50 \%$, dan $37,50 \%$.

Nilai kerapatan jenis tertinggi pada tingkat Pancang di stasiun 1 nilai tertinggi dimiliki oleh $R$. mucronata yaitu 0,39 ind $/ \mathrm{m}^{2}$, sedangkan jenis tersebut memiliki nilai kerapatan relatif sebesar $1,00 \%$. Stasiun 2 nilai tertinggi dimiliki oleh $R$. apiculata yaitu $0,17 \mathrm{ind} / \mathrm{m}^{2}$, diikuti B. gymnorrhiza yaitu $0,16 \%$, dan yang terendah adalah $R$. stylosa yaitu 0,03 ind $/ \mathrm{m}^{2}$, sedangkan masing-masing jenis tersebut memiliki nilai kerapatan relatif sebesar $48,15 \%, 44,44 \%$ dan $7,41 \%$.

Nilai kerapatan jenis tertinggi pada tingkat Tiang di stasiun 1 nilai tertinggi dimiliki oleh $R$. mucronata yaitu $0,17 \mathrm{ind} / \mathrm{m}^{2}$, diikuti $R$. apiculata yaitu 0,03 ind $/ \mathrm{m}^{2}, R$. stylosa yaitu $0,02 \mathrm{ind} / \mathrm{m}^{2}, S$. alba dan $L$. littorea yaitu $0,01 \mathrm{ind} / \mathrm{m}^{2}, C$. tagal yaitu $0,01 \mathrm{ind} / \mathrm{m}^{2}$, sedangkan jenis tersebut memiliki nilai kerapatan relatif sebesar $68,92 \%, 13,51 \%, 6,76 \%, 4,05 \%$, $4,05 \%$, dan $2,70 \%$. Stasiun 2 dimiliki oleh $R$. apiculata yaitu $0,11 \mathrm{ind} / \mathrm{m}^{2}$, diikuti $R$. stylosa yaitu $0,03 \mathrm{ind} / \mathrm{m}^{2}$, dan yang terendah adalah B. gymnorrhiza yaitu $0,01 \%$, sedangkan masing-masing jenis tersebut memiliki nilai kerapatan relatif sebesar $75,56 \%, 17,78 \%$ dan $6,67 \%$.

Nilai kerapatan jenis tertinggi pada tingkat Pohon di stasiun 1 nilai tertinggi dimiliki oleh $S$. alba yaitu 2 ind $/ \mathrm{m}^{2}$, diikuti $R$. mucronata yaitu 1,33 ind $/ \mathrm{m}^{2}$, B. gymnorrhiza yaitu $0,67 \mathrm{ind} / \mathrm{m}^{2}$, yang terendah adalah $R$. apiculata dan $B$. cylindrical yaitu $0,33 \mathrm{ind} / \mathrm{m}^{2}$, sedangkan jenis tersebut memiliki nilai kerapatan relatif sebesar $42,86 \%, 28,57 \%, 14,29 \%$, dan 7,14\%, 7,14\%. Stasiun 2 nilai tertingggi dimiliki oleh $R$. apiculata yaitu $6,00 \mathrm{ind} / \mathrm{m}^{2}$, diikuti B. gymnorrhiza yaitu $2,33 \%$, R. stylosa yaitu $1,67 \mathrm{ind} / \mathrm{m}^{2}$, dan yang terendah adalah $S$. alba 1,00 ind $/ \mathrm{m}^{2}$, sedangkan masing-masing jenis tersebut memiliki nilai kerapatan relatif sebesar $54,55 \%, 21,21 \%, 15,15$ dan $9,09 \%$.

Hasil diatas menunjukkan bahwa nilai kerapatan mangrove tertinggi terdapat di stasiun 1, diduga hal ini dikarenakan kondisi lingkungan di stasiun 1 yang lebih baik untuk pertumbuhan mangrove, dari jumlah individu yang ditemukan pada jenis mangrove dan luas lokasi penelitian dapat dikatakan bahwa kerapatan jenis memiliki hubungan 
Tabel 1. Nilai analisis data tingkat Pohon

\begin{tabular}{|l|c|c|c|c|c|c|c|c|c|c|c|c|c|c|}
\hline \multirow{2}{*}{$\begin{array}{c}\text { Jenis } \\
\text { Mangrove }\end{array}$} & \multicolumn{2}{|c|}{ (Di) } & \multicolumn{2}{c|}{ (RDi) } & \multicolumn{2}{c|}{ (Fi) } & \multicolumn{2}{c|}{ (RFi) } & \multicolumn{2}{c|}{ (Ci) } & \multicolumn{3}{c|}{ (RCi) } & (INP) \\
\hline & St 1 & St 2 & St 1 & St 2 & St 1 & St 2 & St 1 & St 2 & St 1 & St 2 & St 1 & St 2 & St 1 & St 2 \\
\hline B. cylindrical & 0.33 & & 7.14 & & 0.33 & & 11.11 & & 0.3 & & 2.55 & & 20.81 & \\
\hline B. gymnorhiza & 0.67 & 2.33 & 14.3 & 21.21 & 0.67 & 0.67 & 22.22 & 25 & 2.91 & 3.21 & 24.9 & 19.4 & 61.44 & 65.57 \\
\hline R. apiculata & 0.33 & 6 & 7.14 & 54.55 & 0.33 & 1 & 11.11 & 37.5 & 0.26 & 8.65 & 2.26 & 52.1 & 20.5 & 144.18 \\
\hline R. mucronata & 1.33 & & 28.6 & & 1 & & 33.33 & & 2.02 & & 17.3 & & 79.21 & \\
\hline R. stylosa & & 1.67 & & 15.15 & & 0.33 & & 12.5 & & 1.68 & & 10.1 & & 37.75 \\
\hline S. alba & 2 & 1 & 42.9 & 9.09 & 0.67 & 0.67 & 22.22 & 25 & 6.17 & 3.05 & 53 & 18.4 & 118 & 52.5 \\
\hline
\end{tabular}

Keterangan : $\mathrm{Di}=$ Kerapatan jenis, $\mathrm{RDi}=$ Kerapatan relatif, $\mathrm{Fi}=\mathrm{Frekuensi}$ jenis, $\mathrm{RFi}=\mathrm{Frekuensi}$ relatif, $\mathrm{Ci}=$ Penutupan jenis, $\mathrm{RCi}=$ Penutupan Relatif, INP=Indeks Nilai Penting.

antara jarak dan pohon. Jumlah individu yang semakin banyak ditemukan maka memiliki nilai kerapatan semakin tinggi. Kerapatan jenis tertinggi disebabkan oleh subsrat yang cocok, dan kemampuan mangrove beradaptasi dengan kondisi lingkungan. Pada jenis mangrove yang memiliki kerapatan rendah disebabkan tingginya pemanfaatan jenis mangrove, habitat atau subsrat yang tidak cocok, adanya interaksi antara spesies atau ketidak mampuan jenis mangrove beradaptasi dengan kondisi lingkunga.

\section{Frekuensi Jenis dan Frekuensi Relatif Jenis}

Nilai Frekuensi jenis tertinggi pada tingkat Semai di stasiun 1 nilai tertinggi dimiliki oleh $R$. mucronata, $R$. apiculata, $B$. gymnorrhiza nilai sama semua yaitu 0,33 , sedangkan jenis tersebut memiliki nilai frekuensi relatif sebesar 33,33\%. Stasiun 2 nilai tertinggi dimiliki oleh $R$. stylosa yaitu 1 , dan yang terendah adalah $R$. apiculata yaitu 0,67 , sedangkan masing-masing jenis tersebut memiliki nilai frekuensi relatif sebesar $60 \%$, dan $40 \%$.

Nilai Frekuensi jenis tertinggi pada tingkat pancang di stasiun 1 nilai tertinggi dimiliki oleh $R$. mucronata yaitu 0,67 , sedangkan jenis tersebut memiliki nilai frekuensi relatif sebesar $100 \%$. Stasiun 2 nilai tertinggi dimiliki oleh $R$. apiculata dan $B$. gymnorizha yaitu 1 , dan yang terendah adalah $R$. stylosa yaitu 0,33 , sedangkan masing-masing jenis tersebut memiliki nilai frekuensi relatif sebesar $42,86 \%$, dan $14,29 \%$.

Nilai Frekuensi jenis tertinggi pada tingkat Tiang di stasiun 1 nilai tertinggi dimiliki oleh $R$. mucronata yaitu 1, diikuti oleh $B$. cylindrical, $S$. alba, $R$. apiculata, $L$. littorea yaitu 0,67 , dan yang terendah adalah $C$. tagal 0,33 , sedangkan jenis tersebut memiliki nilai frekuensi relatif sebesar $25 \%, 16,67$, dan $8,33 \%$. Stasiun 2 nilai tertinggi dimiliki oleh $R$. apiculata dan $B$. gymnorizha yaitu 1 , dan yang terendah adalah $R$. stylosa yaitu 0,33 , sedangkan masing-masing jenis tersebut memiliki nilai frekuensi relatif sebesar $42,86 \%$, dan $14,29 \%$.

Nilai Frekuensi jenis tertinggi pada tingkat pohon di stasiun 1 nilai tertinggi dimiliki oleh $R$. mucronata yaitu 1, diikuti oleh $B$. gymnorhiza, $S$. alba, yaitu, 0,67 , dan yang terendah adalah $R$. apiculata, dan B. cylindrical yaitu 0,33, sedangkan masing-masing jenis tersebut memiliki nilai frekuensi relatif sebesar $33,33 \%$, 22,22, dan $11,11 \%$. Stasiun 2 nilai tertinggi dimiliki oleh $R$. apiculata yaitu 1 , diikuti $B$. gymnorizha dan $S$. alba yaitu 0,67 , dan yang terendah adalah $R$. stylosa yaitu 0,33 , sedangkan masingmasing jenis tersebut memiliki nilai frekuensi relatif sebesar $37,5 \%, 25 \%$ dan $12,5 \%$.

Frekuensi merupakan salah satu parameter vegetasi yang dapat menunjukan pola distribusi atau sebaran jenis tumbuhan dalam ekosistem atau 
memperlihatkan pola distribusi tumbuhan (Fachrul 2007). Dari semua hasil di atas dapat dijelaskan bahwa nilai frekuensi kehadiran jenis mangrove sangat dipengaruhi oleh banyaknya jumlah suatu jenis yang ditemukan pada setiap kuadran di lokasi penelitian. Makin banyak jumlah kuadran ditemukanya jenis mangrove pada setiap kuadran, maka nilai frekuensi kehadiran jenis mangrove makin tinggi. Tingginya nilai frekuensi relatif yang dimiliki oleh $R$. mucronata dan $R$. apiculata pada 2 (dua) stasiun penelitian, karena ke 2 (dua) jenis ini terdistribusi hampir merata disetiap kuadran dan menempati subsrat berlumpur liat sampai pasir berlumpur liat sampai pasir berlumpur. Hal ini diduga disebabkan karena jenis-jenis ini mampu bertahan hidup di subsrat yang kurang stabil serta mempunyai kemampuan beradaptasi dengan kondisi yang kurang cocok. Sedangkan jenis yang memiliki nilai frekuensi terendah dimiliki oleh $L$. littorea dan C. tagal. Hal ini disebabkan karena ke 2 (dua) jenis ini tidak terdistribusi merata dan hanya terdapat di 1 (satu) kuadran saja. Adanya nilai frekuensi kahadiran terendah pada lokasi penelitian disebabkan karena adanya arus yang membawa buah dari mangrove tersebut, sehingga menyebabkan jenis mangrove yang memiliki nilai frekuensi terendah ini hanya ditemukan 1 individu per jenis. Tingginya tingkat eksploitasi, habitat yang tidak cocok dan adanya interaksi antara jenis, serta ketidak mampuan jenis beradaptasi dengan kondisi lingkungan, menyebabkan rendahnya frekuensi kehadiran jenis mangrove di suatu lokasi, karena frekuensi relatif dipengaruhi oleh frekuensi jenis mangrove.

\section{Penutupan Jenis dan Penutupan Relatif Jenis}

Nilai penutupan jenis pada tingkat tiang di Stasiun 1 nilai tertinggi terdapat pada jenis $R$. mucronata yaitu $21,44 \mathrm{~m}^{2}$, diikuti $R$. apiculata yaitu $5,50 \mathrm{~m}^{2}, S$. alba yaitu $2,05 \mathrm{~m}^{2}$, B. cylindrical yaitu $1,93 \mathrm{~m}^{2}$, C. tagal yaitu $0,93 \mathrm{~m}^{2}$, dan yang terendah adalah $L$. littorea yaitu $0,84 \mathrm{~m}^{2}$, sedangkan nilai penutupan relatif sebesar $66,48 \%, 17,07 \%, 6,35 \%, 5,99 \%$, $2,61 \%$, dan $1,52 \%$. Stasiun 2 nilai tertinggi terdapat pada jenis $R$. apiculata yaitu $16,74 \mathrm{~m}^{2}$, diikuti $R$. stylosa yaitu $3,35 \mathrm{~m}^{2}$, dan yang terendah adalah $B$. gymnorhiza yaitu $1,43 \mathrm{~m}^{2}$, sedangkan nilai penutupan relatif sebesar $77,77 \%, 15,56 \%$, dan $6,67 \%$.

Nilai penutupan jenis pada tingkat pohon di Stasiun 1 nilai tertinggi terdapat pada jenis $S$. alba yaitu $6,17 \mathrm{~m}^{2}$, diikuti $B$. gymnorhiza yaitu $2,91 \mathrm{~m}^{2}$, $R$. mucronata yaitu $2,02 \mathrm{~m}^{2}, R$. apiculata yaitu 20,26 $\mathrm{m}^{2}$, dan yang terendah adalah $B$. cylindrical yaitu $0,30 \mathrm{~m}^{2}$, sedangkan nilai penutupan relatif sebesar $52,95 \%$, $24,94 \%, 17,31 \%, 2,55 \%$, dan $2,55 \%$. Nilai penutupan jenis pada tingkat pohon di Stasiun 2 nilai tertinggi terdapat pada jenis $R$. apiculata yaitu $8,65 \mathrm{~m}^{2}$, diikuti $B$. gymnorrhiza yaitu $3,21 \mathrm{~m}^{2}, S$. alba yaitu $3,05 \mathrm{~m}^{2}$, dan yang terendah adalah $R$. stylosa yaitu $1,68 \mathrm{~m}^{2}$, sedangkan nilai penutupan relatif sebesar $52,13 \%$, $19,36 \%$, $18,41 \%$, dan $10,10 \%$.

Nilai penutupan jenis dan penutupan relatif yang besar tingkat Tiang yaitu jenis $R$. mucronata sedangkan di tingkat Pohon jenis $S$. alba yang paling besar menunjukan bahwa jenis-jenis ini memiiki diameter batang yang besar dan produktivitas yang besar pula sehingga nilai tutupan yang diperoleh juga tinggi. Faktor-faktor yang mempengaruhi nilai tutupan suatu jenis ialah lingkaran batang pohon dan basal area dalam satu lokasi pengambilan sampel. Yang paling berpengaruh dalam menenutukan besarnya diameter batang adalah jenis umur pohon, dengan lamanya pertumbuhan umur suatu pohon, maka pohon tersebut akan bertamabah besar. Pada tingkat Tiang nilai penutupan dari dua stasiun nilai 
tertinggi terdapat di stasiun 1 yaitu jenis R. mucronata $\left(21,44 \mathrm{~m}^{2}\right)$ dan yang terendah adalah jenis $L$. littorea $(0,84$ $\mathrm{m}^{2}$ ), sedangkan nilai penutupan relatif sebesar $(66,48 \%)$ dan (1,52 \%). Nilai penutupan ditingkat Pohon nilai tertinggi terdapat di stasiun 2 yaitu jenis $R$. apicualata $\left(8,65 \mathrm{~m}^{2}\right)$ dan yang terendah terdapat di stasiun 1 yaitu jenis B. cylindrical $\left(0,30 \mathrm{~m}^{2}\right)$, sedangkan nilai penutupan relatif sebesar $2,26 \%$ dan $2,55 \%$.

Dari hasil penelitian menunjukan bahwa $R$. mucronata dan $R$. apiculata memiliki lingkaran batang pohon paling besar sehingga nilai tutupan yang diperoleh tinggi. Faktor penting yang mempengaruhi nilai penutupan suatu jenis ialah lingkaran batang pohon dan basal area dalam satu lokasi pengambilan sampel.

\section{Indeks Nilai Penting}

Indeks Nilai Penting (INP) dengan

nilai $\quad 0-300$ menunjukan keterwakilan jenis mangrove yang berperan dalam ekosistem sehingga, jika nilai penting 300 berarti suatu jenis mangrove memiliki peran dan pengaruh yang penting dalam komunitas mangrove (Bengen, 2004).

Stasiun 1 pada tingkat pertumbuhan Semai nilai penting tertinggi adalah jenis $R$. mucronata yaitu $93,33 \%$ sedangkan nilai terendah adalah jenis $R$. apiculata $60 \%$. Stasiun 2 nilai penting tertinggi adalah jenis $R$. stylosa yaitu $122,5 \%$, sedangkan nilai terendah adalah jenis $R$. apiculata $77,5 \%$.

Stasiun 1 pada tingkat pertumbuhan Pancang nilai penting tertinggi adalah jenis $R$. mucronata yaitu $200 \%$. Stasiun 2 pada tingkat pertumbuhan Pancang nilai penting tertinggi adalah jenis $R$. mucronata yaitu $145,45 \%$, sedangkan nilai terendah adalah jenis $R$. apiculata $54,55 \%$.

Stasiun 1 pada tingkat pertumbuhan Tiang nilai penting tertinggi adalah jenis $R$. mucronata yaitu
$160,39 \%$, sedangkan nilai penting terendah adalah jenis $C$. tagal yaitu $12,56 \%$. Stasiun 2 nilai penting tertinggi adalah jenis $R$. apiculata yaitu $196,18 \%$, sedangkan nilai penting terendah adalah jenis $R$. stylosa yaitu $47, \%$ dan $R$. mucronata yaitu $112,36 \%$.

Stasiun 1 pada tingkat pertumbuhan Pohon nilai penting tertinggi adalah jenis $S$. alba yaitu $118,03 \%$, sedangkan nilai penting terendah adalah $R$. apiculata yaitu $20,5 \%$. Stasiun 2 nilai penting tertinggi adalah jenis $R$. apiculata yaitu $144,18 \%$, sedangkan nilai penting terendah adalah jenis $R$. stylosa yaitu $37,75 \%$ dan $R$. mucronata yaitu $54,43 \%$.

Dari Hasil perhitungan nilai penting menyatakan kepentingan suatu jenis tumbuhan dan juga menggambarkan tingkat penguasaan jenis dalam suatu komunitas. Selain itu, INP juga memberikan suatu gambaran besarnya pengaruh dan peranan suatu jenis dalam suatu komunitas mangrove. Untuk tingkat Semai nilai penting tertinggi terlihat di stasiun 2 yaitu jenis $R$. stylosa $(122,5 \%)$ sedangkan nilai yang terendah di stasiun 1 yaitu jenis $B$. gymnorrhiza $(46,67 \%)$. Tingkat Pancang nilai tertinggi terdapat di stasiun 1 yaitu jenis R. mucronata (200\%) sedangkan nilai terendah di stasiun 2 yaitu jenis $R$. stylosa $(21,69 \%)$. Tingkat Tiang nilai penting tertinggi di stasiun 2 adalah jenis $R$. apiculata $(196,18 \%)$ sedangkan nilai penting terendah di stasiun 1 C. tagal $(12,56 \%)$. Tingkat Pohon nilai tertinggi terdapat di stasiun 1 yaitu jenis $S$. alba $(118,03 \%)$ sedangkan nilai terendah terdapat di stasiun 1 yaitu jenis $R$. apiculata $(20,5 \%)$.

Beradasarkan hasil penelilitian di atas diketahui bahwa setiap tempat yang berbeda didominasi oleh jenis yang berbeda pula, dengan demikian kemampuan jenis yang hidup pada suatu tempat sangat tergantung kemampuan jenis untuk hidup pada suatu tempat 
sangat tergantung kemampuannya beradaptasi terhadap kondisi lingkungan di tempat tersebut. Menurut Bengen (2003) nilai penting digunakan untuk melihat pertumbuhan jenis mangrove dalam suatu komunitas, dapat dilihat dari analisis kongdisi vegetasi yang menunjukan peranan suatu jenis mangrove dalam komunitas mangrove. Nilai penting dari tiap jenis mangrove, sangat tergantung kondisi pertumbuhan mangrove. Mangrove untuk tumbuhan dengan baik, memerlukan sejumlah faktor pendukung seperti ketersediaan nutrient atau bahan organik, susbrat yang cocok, kondisi perairan yang stabil dan tidak adanya ekspolitasi mangrove oleh masyarakat setempat.

\section{Indeks Keanekaragaman, Kekayaan, Keseragaman, dan Dominansi}

Soegianto (1994) menjelaskan

bahwa keanekaragaman jenis digunakan untuk mengukur kemampuan suatu komunitas untuk menjaga dirinya terhadap gangguan dan dapat digunakan untuk mengukur kekayaan komunitas. Hal ini dapat dilihat dari jumlah jenis dalam suatu kawasan semakin banyak jumlah jenis maka semakin tinggi nilai keanekaragaman. Kenekaragaman jenis vegetasi mangrove diketahui dengan indeks keanekaragaman ShannonWiener (Ludwig dan Reynold, 1988).

$$
\text { Tingkat Semai adapun }
$$

keanekaragaman tertinggi dari kedua stasiun terdapat pada stasiun 1 dengan jumlah $H^{\prime}=0,93$. Hal ini berarti bahwa stasiun 1 memiliki keanekaragaman yang lebih melimpah, sedangkan di stasiun 2, keanekaragamannya rendah. Kekayaan jenis dan individu dianalisis dengan menghitung nilai indeks kekayaan. Dalam penelitian ini nilai kekayaan terbesar terdapat pada stasiun 1 dengan nilai 0,74 sedangkan nilai terendah terdapat di stasiun 2 yaitu 0,48 . Nilai Keseragaman yang tertinggi terdapat di stasiun 2 dengan nilai 0,95 sedangkan nilai terendah di stasiun 1 dengan nilai 0,84. Nilai Dominansi yang tertinggi terdapat di stasiun 2 dengan nilai 0,66, hal ini berarti bahwa stasiun 2 memiliki kriteria dominansi tinggi sedangkan yang terendah di stasiun 1 dengan nilai 0,45 (Gambar 1).

Tingkat Pancang keanekaragaman tertinggi dari kedua stasiun terdapat pada stasiun 2 dengan jumlah $H^{\prime}=0,91$. Hal ini berarti bahwa stasiun 2 memiliki keanekaragaman yang lebih melimpah, sedangkan di stasiun 1 keanekaragamannya rendah. Kekayaan jenis dan individu dianalisis dengan menghitung nilai indeks kekayaan. Dalam penelitian ini nilai kekayaan terbesar terdapat pada stasiun 2 dengan nilai 0,61 , dan yang terendah yaitu stasiun 1 dengan nilai 0,00. Nilai Keseragaman yang tertinggi terdapat di stasiun 2 dengan nilai 0,82 sedangkan nilai terendah di stasiun 1 dengan nilai 0.00. Nilai Dominansi yang tertinggi terdapat di stasiun 1 dengan nilai 1,00, hal ini berarti bahwa stasiun 1 memiliki kriteria dominansi tertinggi sedangkan yang terendah di stasiun 2 dengan nilai 0,43 (Gambar 2).

Untuk tingkat Tiang adapun keanekaragaman tertinggi dari kedua stasiun terdapat pada stasiun 1 jumlah $H^{\prime}=1,07$. Hal ini berarti bahwa stasiun 1 memiliki keanekaragaman yang lebih melimpah, sedangkan di stasiun 2 keanekaragamannya rendah. Kekayaan jenis dan individu dianalisis dengan menghitung nilai indeks kekayaan. Dalam penelitian ini nilai kekayaan terbesar terdapat pada stasiun 1 dengan nilai 1,16 sedangkan nilai terendah nilai rendah yaitu stasiun 2 dengan nilai 0,53. Nilai Keseragaman yang tertinggi terdapat di stasiun 2 dengan nilai 0,64, sedangkan terendah stasiun 1 dengan nilai 0,60 . Nilai Dominansi yang tertinggi terdapat di stasiun 2 dengan nilai 0,61, terendah yaitu stasiun 1 dengan nilai 


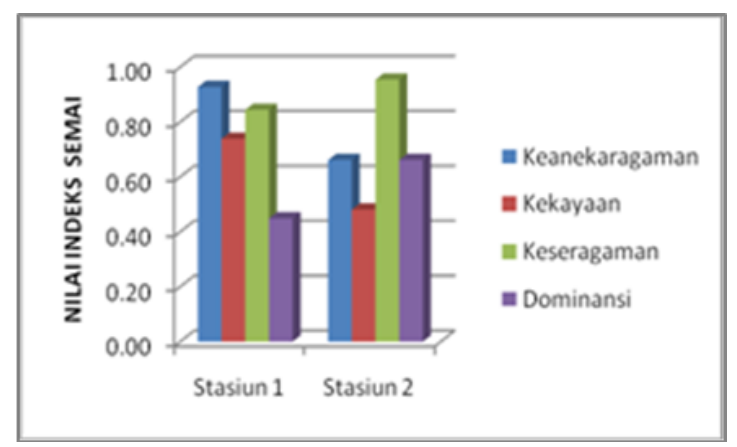

Gambar 1. Indeks Keanekaragaman, Kekayaan, Keseragaman, dan Dominansi tingkat Semai di Stasiun 1, 2.

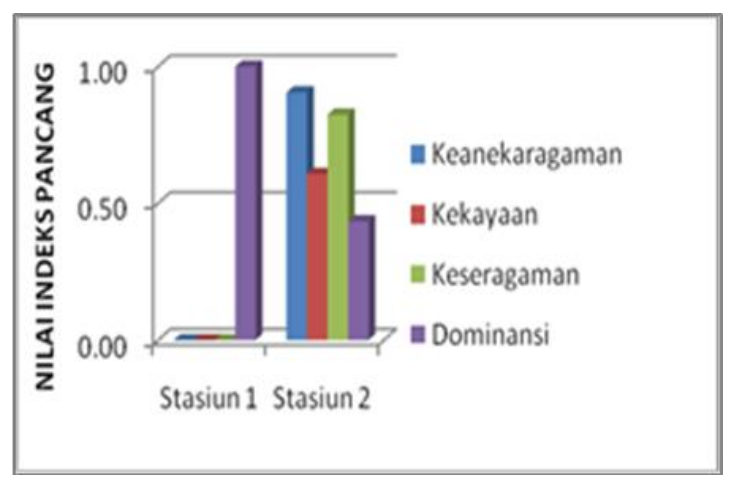

Gambar 2. Indeks Keanekaragaman, Kekayaan, Keseragaman, dan Dominansi tingkat Pancang di Stasiun 1, 2.

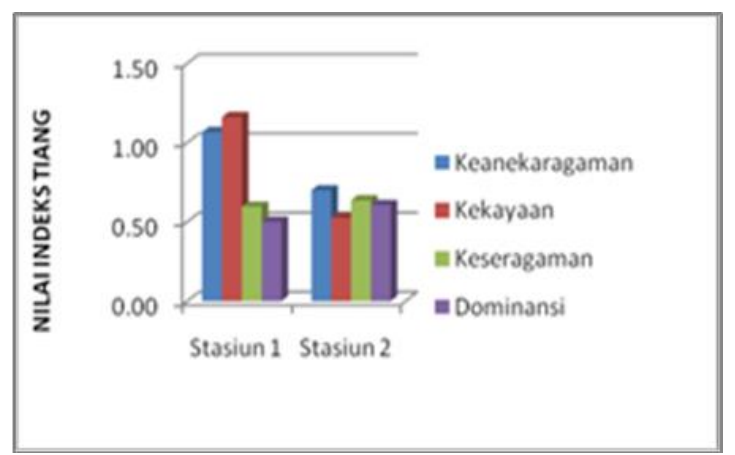

Gambar 3. Indeks Keanekaragaman, Kekayaan, Keseragaman, dan Dominansi tingkat Tiang di Stasiun 1, 2.

0,50. Hal ini berarti bahwa stasiun 2 memiliki Dominansi sedang (Gambar 3).

$$
\text { Tingkat Pohon adapun }
$$
keanekaragaman tertinggi dari kedua stasiun terdapat pada stasiun 1 dengan

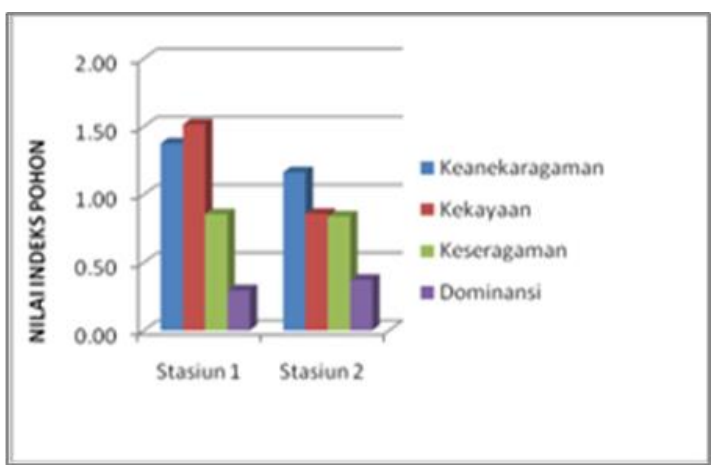

Gambar 4. Indeks Keanekaragaman, Kekayaan, Keseragaman, dan Dominansi tingkat Pohon di Stasiun 1, 2.

jumlah $H^{\prime}=1,38$. Hal ini berarti bahwa stasiun 1 memiliki keanekaragaman yang lebih melimpah, sedangkan di stasiun 2 yaitu $H^{\prime}=$ 1,16 keanekaragamannya rendah. Kekayaan jenis dan individu akan dapat dianalisis dengan menghitung nilai indeks kekayaan. Nilai kekayaan terbesar terdapat pada stasiun 1 dengan nilai 1,52 , nilai terendah stasiun 2 nilai 0,86 . Hal ini didasarkan pada jumlah individu dalam setiap stasiun, meskipun jenisnya sama ataupun sedikit akan tetapi jika jumlah individunya banyak akan berakibat kekayaan individu dalam suatu komunitas ini tinggi. Tingginya nilai kekayaan dapat disebabkan oleh kondisi lingkungan yang stabil, habitat yang cocok dan suplai air laut yang cukup bagi pertumbuhan mangrove. Nilai Keseragaman yang tertinggi terdapat di stasiun 1 dengan nilai 0,85 , nilai rendah stasiun 2 yaitu 0,84 . Nilai Dominansi yang tertinggi terdapat di Stasiun 2 dengan nilai 0,37 , yang terendah yaitu stasiun 1 adalah 0,30 . Hal ini berarti bahwa stasiun 2 memiliki Dominansi tinggi (Gambar 4).

Hasil penelitian yang didapat di dua stasiun dengan memiliki keanekaragaman tertinggi di setiap stasiun dengan tingkat Semai, Pancang, Tiang dan pohon, berarti jenis mangrove di dua stasiun kurang mendominasi. Namun dari dua stasiun penelitian yang 
memiliki keanekaragaman tertinggi ternyata berdasarkan kriteria yang dikemukakan oleh Shannon-Wiener (1963) dalam Odum (1971), maka indeks keanekaragaman $\left(\mathrm{H}^{\prime}\right)$ pada tingkat Semai rendah yaitu $H^{\prime}$ berkisaran antara 0,93 $\left(H^{\prime}<1\right)$, berarti ada salah satu jenis mangrove yang mendominasi dengan kriteria dikemukakan oleh (Odum, 1971) yaitu $C$ berkisar antara 0,66 $(0,5<\mathrm{D} \leq 0,75)$, maka dominansi sedang. Sedangkan tingkat Pancang, Tiang, Pohon dengan kriteria sedang yaitu $\mathrm{H}^{\prime}$ berkisaran antara 0,91 - 1,07 - 1,38 $\left(1<\mathrm{H}^{\prime}<3\right)$, dari tingkat Pancang, Tiang dan Pohon dengan kriteria sedang berarti nilai dominansi rendah yaitu $0,43-0,50$ 0,30 .

Ludwig and Reynold (1988) mengemukakan bahwa makin besar $\mathrm{H}^{\prime}$ suatu komunitas maka semakin mantap pula komunitas tersebut. Nilai $H^{\prime}=0$ dapat terjadi bila hanya satu jenis dalam satu contoh (sampel) dan $\mathrm{H}^{\prime}$ maksimal bila semua jenis mempunyai jumlah individu yang sama dan ini menujukkan kelimpahan terdistribusi secara sempurna. Keanekaragaman jenis merupakan indikator dari kemantapan atau kestabilan dari suatu lingkungan pertumbuhan. Kestabilan yang tinggi menunjukkan tingkat kompleksitas yang tinggi, hal ini disebabkan karena terjadi interaksi yang tinggi pula, sehingga akan mempunyai kemampuan lebih tinggi dalam menghadapi gangguan terhadap kompenen-komponennya. Jika indeks keanekaragaman yang stabil, maka masing-masing jenis akan berkesempatan untuk dapat melangsungkan daur kehidupan yang lebih teratur, efisien, dan produktif. Dengan memperhatikan keanekargaman dalam komunitas dapat diperoleh gambaran tentang kedewasaan organism suatu komunitas, makin tinggi organisme di dalam suatu komunitas tersebut sehingga keanekaragamannya lebih tinggi.

\section{Variabel Lingkungan}

Variabel lingkungan merupakan faktor-faktor lingkungan yang mempengaruhi pertumbuhan mangrove. Adapun beberapa variabel lingkungan yaitu salinitas dan suhu. Menurut Anonim (2015), salinitas optimum yang dibutuhkan mangrove untuk tumbuh berkisar antara 10-30 ppt. Salinitas secara langsung dapat mempengaruhi laju pertumbuhan dan zonasi mangrove, hal ini terkait dengan frekuensi penggenangan. Salinitas air akan meningkat jika pada siang hari cuaca panas dan dalam keadaan pasang. Selanjutnya Supriharyono (2000) menambahkan bahwa selain salinitas, suhu air juga merupakasn faktor penting yang menemukan kehidupan tumbuhan mangrove. Menurut Aksornkoae (1993) kisaran suhu lingkungan hutan mangrove yang alami berkisar antara $21-30{ }^{\circ} \mathrm{C}$, suhu air berada pada kisaran suhu $28{ }^{\circ} \mathrm{C}$. Suhu pembatas kehidupan mangrove adalah suhu yang rendah dan kisaran suhu musiman. Suhu yang baik untuk kehidupan mangrove tidak kurang dari $20{ }^{\circ} \mathrm{C}$, sedangkan kisaran musiman suhu tidak melebihi $5{ }^{\circ} \mathrm{C}$. Dari hasil pengukuran di lokasi pengamatan terlihat bahwa kondisi salinitas dan suhu pada lokasi penelitian mengindikasikan bahwa kondisi ini mendukung kelangsungan hidup dari mangrove. Berdasarkan hasil pengukuran salinitas yang berkisar antara 29-33 ppt di dua stasiun penelitian, menunjukan kisaran yang masih baik bagi kelangsungan hidup mangrove. Salinitas optimum yang dibutuhkan mangrove untuk tumbuh berkisar antara 10-30 ppt, sedangkan hasil pengukuran yang didapat salinitas air meningkat jika pada siang hari cuaca panas dan dalam keadaan pasang. Pada waktu pengambilan data, saat itu mengalami musim kemarau sehingga salinitas di Pulau Mantehage tinggi berkisar antara 33 ppt Tingginya salinitas disebabkan kurangnya air tawar (air 
hujan) atau mengalami musim kemarau berkepanjangan (EI Nino) dan kurangnya tiupan angin serta penyinaran matahari yang begitu efektif sehingga terjadi pengguapan yang tinggi.

Hasil pengukuran suhu yang di ukur pada lokasi penelitian menunjukkan hasil yang bervariasi yaitu berkisar antara 27 hingga $30{ }^{\circ} \mathrm{C}$. Kisaran nilai suhu yang terendah pada lokasi penelitian umumnya di pulau bagian dalam hutan mangrove (stasiun 2). Hal ini disebabkan karena kerapatan pohon yang cukup tinggi, sehingga menghalangi masuknya intensitas cahaya ke dalam ekosistem mangrove. Di empat stasiun masih dalam kisaran suhu perairan tropik yaitu berkisar antara $25-30{ }^{\circ} \mathrm{C}$ dan merupakan suhu yang cocok bagi produksi daun mangrove. Jenis tekstur subsrat yang ditemukan pada komunitas mangrove di Pulau Mantehage berupa lumpur liat sampai pasir berlumpur. Tekstur subsrat yang dominan ialah lumpur, sehingga baik bagi tumbuhan mangrove yang jenis Rhizophora spp. Hal ini dapat dikatakan bahwa keadaan vegetasi mangrove di Pulau Mantehage diduga cukup didukung oleh faktor lingkungan yang ada di sekitarnya.

\section{KESIMPULAN}

Dari penelitian yang telah dilaksanakan dapat disimpulkan bahwa : dentifikasi jenis-jenis mangrove yang terdapat di dua stasiun di Pulau Mantehage terdiri dari 8 (delapan) jenis mangrove yaitu : $R$. mucronata, $R$. apiculata, $R$. stylosa, B. gymnorrhiza, B. cylindrical, C. tagal, S. alba, dan L. littorea dari 3 (tiga) famili yaitu : Rhizophoraceae, Sonneratiaceae, dan Combretaceae.

Nilai kerapatan jenis tertinggi yaitu $S$. alba yaitu $2 \mathrm{ind} / \mathrm{m}^{2}$, dengan kerapatan relatif $100 \%$. Nilai frekuensi tertinggi 1,00 yaitu jenis $R$. mucronata, $R$. apiculata dan $B$. gymnorrhiza di tingkat Tiang dan Pohon. Nilai penutupan tertinggi yaitu jenis $R$. apiculata $(21,44$ $\mathrm{m}^{2}$ ) terdapat di stasiun 1 tingkat Tiang. Indeks nilai penting $R$. apiculata $(196,18 \%)$ di stasiun 2 tingkat Tiang sedangkan tingkat Pohon nilai tertinggi yaitu jenis $R$. apiculata (144,18\%). Analisis INP yang terendah dari semua stasiun yaitu jenis $C$. tagal, $B$. cylindrical, dan L. littorea. Kondisi ekologi mangrove di Pulau Mantehage dari hasil analisis vegetasi mangrove dengan melihat kriteria keanekaragaman rendah maka di Pulau Mantehage menunjukkan ekosistem belum stabil ( $\left.H^{\prime}=0,93, H^{\prime}=0,91, H^{\prime}=1,07, H^{\prime}=1,38\right)$. Keseragaman dari tingkat Semai, Pancang, Tiang dan Pohon dari dua stasiun memiliki keseragaman merata nilainya (tingkat Semai=0,95, Pancang $=0,82$, Tiang $=64 \quad$ dan Pohon $=0,85)$. Sedangkan nilai dominansi di Pulau Mantehage memiliki nilai tertinggi (tingkat Semai $=0,66$, Pancang $=1,00, \quad$ Tiang $=0,61 \quad$ dan Pohon=0,37). Variabel lingkungan merupakan salah satu faktor lingkungan yang mempengaruhi pertumbuhan mangrove yaitu salinitas, suhu dan subsrat. Kisaran salinitas 29-33 ppt, suhu 27-30 ${ }^{\circ} \mathrm{C}$ dan subsrat yang dominan ialah lumpur, sehingga baik bagi tumbuhan mangrove jenis Rhizophora spp. dari hasil yang didapat faktor-faktor lingkungan tersebut masih tergolong baik bagi pertumbuhan mangrove.

\section{DAFTAR PUSTAKA}

Anonim, 2015. Pembatas dalam Ekosistem Mangrove. https://www.google.com/?hl=id\#hl= id\&q=faktor (Diunduh tanggal 15 Mei 2015). Pukul 14.35.

Aksornkoae, S. 1993. Ecology and Management of Mangrove. The IUCN wetlands programme. Bangkok. Thaliland. 176 hal. 
Bengen, D.G. 2003. Teknik Pengambilan Contoh dan Analisis Data Biofisik Sumberdaya Peisisir - Sinopsis, Pusat Kajian Sumberdaya Pesisir dan Lautan IPB, Bogor.

Bengen, D.G. 2004. Pedoman Teknis Pengenalan Dan Pengelolaan Ekosistem Mangrove. Pusat kajian Sumberdaya pesisir dan lautan. Institut pertanian Bogor. 59 hal

Fachrul, M.F. 2007. Metode Sampling Bioekologi. PT Bumi Aksara. Jakarta.

Ludwig, J.A., Reynolds, J.V. 1988. Stasistical ecology a primer in methods and computing. John wiley and sons. New York - Chichester Brisane - Toronto - Singapore. 202 hal.

Nybakken, J.W. 1992. Biologi Laut suatu Pendekatan Ekologi. Alih Bahasa oleh Eidman, M., Koesoebiono, Bengen, D.G., Hutomo, M., Sukardjo, S. PT.Gramedia Pustaka Utama. Jakarta, Indonesia. 187 hal.

Odum, E.P. 1971. Dasar-Dasar Ekologi. Edisi ketiga. Gadjah Mada University Press. Yogyakarta. 697 hal.

Soegianto, A. 1994. Ekologi kuantitatif. Penerbit usaha Nasional. Surabaya. 173 hal.

Supriharyono. 2000. Pelestarian dan Pengelolaan Sumberdaya Alam di Wilayah Pesisir Tropis. PT Gramedia pustaka utama. Jakarta.

Waryono, T. 2002. Restorasi Ekologi Hutan Mangrove. Dalam Seminar
Nasional Mangrove. DKI Jakarta. 9 hal. 